\title{
IMPLEMENTATION OF INTEGRATED SOLID WASTE MANAGEMENT IN TURKEY BASED ON CIRCULAR ECONOMY
}

\author{
Oylum Gökkurt Baki* \\ "Sinop University, Engineering and Architecture Faculty, Environmental Engineering Department, \\ 57000, Sinop, Turkey; \\ *Corresponding Author Oylum Gökkurt Baki, e-mail: ogbaki@ @inop.edu.tr;
}

Received May 2021; Accepted June 2021; Published August 2021;

DOI: https://doi.org/10.31407/ijees11.405

\begin{abstract}
Solid waste still remains an urban problem in many places in Turkey. One of the most important principles of waste management strategy recently in Turkey, prevention of waste generation at source and/or waste minimization. In the legal regulations in Turkey, waste minimization, reuse of wastes, recycling materials and energy are handled as priority. These principles, which are also included in our legislation, actually support circular economy (CE) practices. At the same time, integrated solid waste management (ISWM) adopts a principle based on the 3R approach (reduce, reuse and recycle) aiming to optimize solid waste management for all waste generating sectors and all stakeholders. In the circular economy, the principles of "reduce, reuse, recycle (reduce, reuse, recycle-3R)" is $3 \mathrm{R}$ principles are absolutely valid. It aims to design wastes so that they can be included in the system and maximize resource recovery. The aim of the study is to reveal the strategy of waste management in Turkey and to indicate the point where the studies have reached in the circular economy (CE) approach. In addition, to emphasize the importance and necessity of applications of circular economy approach in solid waste management. In that the circular economy is an important approach both to tackle environmental problems and to encourage sustainable production and consumption.
\end{abstract}

Keywords: circular economy, life cycle assessment, integrated solid waste management, 3R approach, principles, Turkey. 